\title{
PHCCC, a Specific Enhancer of Type 4 Metabotropic Glutamate Receptors, Reduces Proliferation and Promotes Differentiation of Cerebellar Granule Cell Neuroprecursors
}

\author{
A. M. Canudas, ${ }^{1}$ V. Di Giorgi-Gerevini, ${ }^{1}$ L. Iacovelli, ${ }^{1,3}$ G. Nano, ${ }^{1}$ M. D'Onofrio, ${ }^{3}$ A. Arcella, ${ }^{3}$ F. Giangaspero, ${ }^{2}$ C. Busceti, ${ }^{3}$ \\ L. Ricci-Vitiani, ${ }^{4}$ G. Battaglia, ${ }^{3}$ F. Nicoletti, ${ }^{1,3}$ and D. Melchiorri ${ }^{1}$ \\ Departments of ${ }^{1}$ Human Physiology and Pharmacology and ${ }^{2}$ Experimental Medicine, University of Rome La Sapienza, 00185 Rome, Italy, ${ }^{3}$ Istituto \\ Neurologico Mediterraneo Neuromed, 86077 Pozzilli, Italy, and ${ }^{4}$ Department of Hematology, Istituto Superiore di Sanità, 00185 Rome, Italy
}

\begin{abstract}
Exposure of immature rat cerebellar granule cell cultures to the type 4 metabotropic glutamate (mGlu4) receptor enhancer $N$-phenyl-7(hydroxyimino)cyclopropa[b]chromen-1a-carboxamide (PHCCC) reduced $\left[{ }^{3} \mathrm{H}\right]$ thymidine incorporation. Its action was sensitive to the growth conditions and was attenuated by two mGlu4 receptor antagonists. An antiproliferative action of PHCCC was also seen in cultures from wild-type, but not mGlu4, knock-out mice. At least in rat cultures, PHCCC was not neurotoxic and enhanced neuritogenesis. Although PHCCC reduced the increase in CAMP formation and phospho-AKT levels induced by forskolin, none of these transduction pathways significantly contributed to the reduction of $\left[{ }^{3} \mathrm{H}\right]$ thymidine incorporation. Interestingly, PHCCC reduced the expression of Gli-1, a transcription factor that mediates the mitogenic action of Sonic hedgehog. Finally, we treated newborn rats with PHCCC either intracerebrally (infusion of $5 \mathrm{nmol} / 2 \mu \mathrm{l}$ in the cerebellar region once every other day) or systemically $(5 \mathrm{mg} / \mathrm{kg}$, i.p., once daily) from postnatal days 3-9. Local infusion of PHCCC induced substantial changes in the morphology of the developing cerebellum. In contrast, systemic injection of PHCCC induced only morphological abnormalities of the cerebellar lobule $\mathrm{V}$, which became visible $11 \mathrm{~d}$ after the end of the treatment. These data suggest that mGlu4 receptors are involved in the regulation of cerebellar development.
\end{abstract}

Key words: type 4 metabotropic glutamate receptor; PHCCC; cerebellar granule cell neuroprecursors; proliferation; differentiation; development

\section{Introduction}

A major challenge in developmental neurobiology is the identification of extracellular signals that regulate the proliferation of neuroprogenitor cells and drive their differentiation into a specific neuronal phenotype. Glutamate reversibly decreases the proliferation of neuroprogenitors in embryonic cortical explants through the activation of AMPA/kainate receptors (Lo Turco et al., 1995). In addition, NMDA receptor blockade increases the density of proliferating granule cell precursors in the dentate gyrus (Gould et al., 1994; Cameron et al., 1995). Metabotropic glutamate $(\mathrm{mGlu})$ receptors are developmentally regulated (Nicoletti et al., 1986; Dudek and Bear, 1989; Catania et al., 1994; van den Pol et al., 1994; Kinzie et al., 1995; Valerio et al., 1997; Furuta and Martin, 1999; Zirpel et al., 2000) and are involved in different aspects of developmental plasticity (Huber et al., 1998, 2002; Flint et al., 1999; Catania et al., 2001; Hannan et al., 2001). Heck et al. (1997) have found that P19 embryocarcinoma cells constitutively express mGlu2 and mGlu4 receptor subtypes, whereas all other

\footnotetext{
Received April 7, 2004; revised Sept. 16, 2004; accepted Sept. 20, 2004

This work was supported by Telethon Grant Italy 1238.

Correspondence should be addressed to Dr. Daniela Melchiorri, Department of Human Physiology and Pharmacology, University of Rome La Sapienza, Piazzale Aldo Moro, 6, 00185 Rome, Italy. E-mail: daniela.melchiorri@uniroma1.it.

D0I:10.1523/JNEUROSCI.3229-04.2004

Copyright $\odot 2004$ Society for Neuroscience $\quad 0270-6474 / 04 / 2410343-10 \$ 15.00 / 0$
}

subtypes (mGlu1, $-3,-5,-7$, and -8 receptors) become expressed when cells acquire a neuronal phenotype in response to retinoic acid. The study of mGlu receptors is now facilitated by the availability of selective allosteric modulators, which amplify or depress receptor function independently of the concentrations of ambient glutamate (for review, see Schoepp et al., 1999). Using the selective mGlu4 receptor enhancer $N$-phenyl-7-(hydroxyimino)cyclopropa[b]chromen-1a-carboxamide (PHCCC) (Maj et al., 2003), we examined the role of mGlu4 receptors in the early development of cerebellar granule cells. These cells originate from granule neuroprecursors (GNPs) that extensively proliferate in the external granular layer of the cerebellar cortex during the first 3 weeks of postnatal life (Altman and Bayer, 1996). Postmitotic GNPs migrate inward across the cerebellar cortex up to the internal granular layer, where they differentiate into mature granule cells. GNP proliferation is supported by a number of factors secreted by neighbor cells, such as insulin-like growth factor I (IGF-I), epidermal growth factor, and Sonic hedgehog (SHH) (Ye et al., 1996; Schwartz et al., 1997; Dahmane and Ruizi-Altaba, 1999; Wallace, 1999; Wechsler-Reya and Scott, 1999). Gain-of-function mutations of the SHH pathway are associated with high rates of medulloblastoma, a tumor that originates from GNPs (Hahn et al., 1996; Provias and Becker, 1996). The specific signals that stop GNP proliferation and drive their differentiation into granule cells are not clearly identified, although pituitary 
adenylyl cyclase-activating peptide (PACAP) and proteins of the extracellular matrix have been implicated (Pons et al., 2001; Nicot et al., 2002). Glutamate is a potential candidate because it can be released in the vicinity of the external granular layer by the ascending axons of differentiated granule cells, as well as by resident glial cells. We now report that activation of mGlu4 receptors reduces GNP proliferation and promotes early neuritogenesis in culture; in addition, a postnatal treatment with PHCCC in rats reduces the weight of the mature cerebellum and induces morphological abnormalities of the central lobe.

\section{Materials and Methods}

Materials. Monoclonal anti-phospho-extracellular signal-regulated kinase (ERK)1/ERK2 and polyclonal anti-phospho-AKT antibodies were from Cell Signaling Technology; polyclonal anti-ERK1/ERK2 and polyclonal anti-Gli-1 antibodies were from Santa Cruz Biotechnology (Santa Cruz, CA); monoclonal anti- $\beta$-actin antibody was from Sigma-Aldrich (Milan, Italy); monoclonal anti-5-bromo-2'-deoxyuridine (BrdU) antibody was from Becton Dickinson (Mountain View, CA); and polyclonal anti-mGluR4 was from Upstate Biotechnology (Lake Placid, NY). The cytotoxicity detection kit [lactate dehydrogenase (LDH)] was from Roche (Berlin, Germany); $\left[{ }^{3} \mathrm{H}\right]$ thymidine and the radioimmunoassay kit for cAMP determination (RPA 509) were from Amersham (Little Chalfont, UK).

Drugs. PHCCC, CPPG [(RS)-a-cyclopropyl-4-phosphonophenylglycine], $(R S)$-a-methylserine-O-phosphate (MSOP), L- $(+)$-2-amino4-phosphonobutyric acid (L-AP-4), (2S)-2-amino-2-[(1S,2S)-2carboxycycloprop-1-yl]-3-(xanth-9-yl) propanoic acid (LY341495), 7-(hydroxyimino)cyclopropa [b]chromen-1a-carboxylate ethyl ester (CPCCOEt), 2-methyl-6-(phenylethynyl)pyridine (MPEP), and $\alpha$-methyl-4-phosphonophenylglycine (MPPG) were purchased from Tocris Cookson (Bristol, UK). In cell culture experiments, PHCCC was dissolved in DMSO. The final concentration of DMSO was $0.1 \%$. $1 R, 4 R, 5 S, 6 R$-2-Oxa-4-aminobicyclo[3.1.0] hexane-4,6-dicarboxylate (LY379268) was kindly donated by Eli Lilly; forskolin, insulin and 8Br-cAMP were from Sigma-Aldrich; UO126 and LY294002 were purchased from Promega (Milan, Italy).

Cell cultures. Primary cultures of cerebellar granule cells were prepared from Sprague Dawley rats (Charles River, Calco, Italy), as described previously (Nicoletti et al., 1986), except that we used 5- to 6-d-old pups. Cultures were purified by centrifugation on a Percoll (Sigma-Aldrich) $30-60 \%$ step gradient (Gao et al., 1991). Cells at the 30-60\% interface were collected and washed in PBS. Cells were plated on $35 \mathrm{~mm}$ dishes precoated with $10 \mu \mathrm{g} / \mathrm{ml}$ poly-L-lysine $\left(1 \times 10^{6}\right.$ cells/well $)$ in three different culture media: (1) basal Eagle's medium (BME; Invitrogen, San Diego, CA) containing 10\% fetal calf serum (FCS) and $25 \mathrm{~mm} \mathrm{~K}^{+}$; (2) BME without serum and $\mathrm{K}^{+}$supplementation; (3) BME with $10 \%$ FCS but without $\mathrm{K}^{+}$supplementation; and (4) a chemically defined medium (CDM) composed of Neurobasal with N2 supplement, 1 mM piruvate, 2 $\mathrm{mm}$ glutamine, and $100 \mu \mathrm{g} / \mathrm{ml}$ bovine serum albumin (all from Invitrogen). Characterization of the cultures after $24 \mathrm{hr}$ in vitro showed that $97 \pm 2.4 \%$ of the cells (three microscopic fields from three dishes) were differentiated granule cells or granule cell precursors (with a typical rounded and small cell body); $<1 \%$ of glial fibrillary acidic protein (GFAP)-positive or glutamate decarboxylase-65-positive cells were present as contaminants. PC12 cells (a rat pheocromocytoma cell line) were cultured in DMEM supplemented with $2 \mathrm{~mm}$ glutamine and $10 \%$ FCS; U87MG cells, a continuous line of human glioma, were cultured in DMEM-Glutamax plus 10\% FCS. Human embryonic kidney (HEK) 293 cells were cultured in DMEM and transfected as described previously (Iacovelli et al., 2004).

Preparation of cultured granule cells from wild-type and $m G l u 4$ receptor knock-out mice. Homozygous mGlu4-deficient mice were purchased from The Jackson Laboratory (Bar Harbor, ME), and wild-type CD1 mice were purchased from Charles River. The genotype at the mGlu4 receptor locus was confirmed by Southern blotting, and multiplied primer PCR was performed on tail biopsy samples [for a detailed description, see Pekhletski et al. (1996)]. Cultures were prepared from the cere- bellum of 5- to 6-d-old pups. Cells were grown for $1 \mathrm{~d}$ in BME in the absence or presence of $10 \%$ FCS without any supplement of $\mathrm{KCl}$. Cultures were used exclusively for studies of $\left[{ }^{3} \mathrm{H}\right]$ thymidine uptake.

$\left[{ }^{3} \mathrm{H}\right]$ thymidine uptake. Cerebellar granule cells were seeded in 6-well plates at a density of $10^{6}$ cells/well. The drugs were applied to the cells 40 min after plating, and the stimulation was continued for $17 \mathrm{hr}$. $\left[{ }^{3} \mathrm{H}\right]$ thymidine $(1 \mu \mathrm{Ci} / \mathrm{ml})$ was added for the last $15 \mathrm{hr}$. U87MG glioma cells were seeded in 24-well plates at a density of $2.5 \times 10^{4}$ cells/well and serum starved for $48 \mathrm{hr}$, and PC12 cells were seeded in 24-well plates at a density of $3.5 \times 10^{5}$ cells/well and serum starved for $24 \mathrm{hr}$. Both U87MG and PC12 cells were challenged with drugs and with $10 \%$ FCS or with 10 $\mathrm{ng} / \mathrm{ml}$ epidermal growth factor (EGF) for $16-18 \mathrm{hr}$, and $\left[{ }^{3} \mathrm{H}\right]$ thymidine $(1 \mu \mathrm{Ci} / \mathrm{ml})$ was added for the last $15 \mathrm{hr}$. HEK 293 cells were serum starved $24 \mathrm{hr}$ after transfection, for 16-18 hr. Cells were challenged with drugs for $24 \mathrm{hr}$, and $\left[{ }^{3} \mathrm{H}\right.$ ] thymidine $(1 \mu \mathrm{Ci} / \mathrm{ml})$ was added for the last $15 \mathrm{hr}$. At the end of the incubation, cells were washed extensively in ice-cold PBS and incubated for at least $10 \mathrm{~min}$ with $0.5 \mathrm{M} \mathrm{HClO}_{4}$. Cells were washed twice with $0.5 \mathrm{M} \mathrm{HClO}_{4}$ and once with ethanol. The precipitates were solubilized with $0.5 \mathrm{M} \mathrm{NaOH}$, and aliquots from each sample were collected for liquid scintillation counting.

BrdU staining in culture. BrdU was applied to cultures grown in serumfree BME $1 \mathrm{hr}$ after plating and maintained for the following 16-20 hr. Immunocytochemistry was performed using monoclonal BrdU antibodies (1:20 dilution; Becton Dickinson) and anti-mouse biotinylated secondary antibody (Vector Laboratories, Burlingame, CA). Staining was developed using 3,3'-diaminobenzidine (ABC Elite kit; Vector Laboratories).

Transduction of rat cultured granule cells with lentiviral vectors. Gene transfer was performed by using pRRLsin.cPPT.hCMV.GFP.Wpre and pRRLsin.cPPT.hPGK.GFP.Wpre, new variants of third-generation lentiviral vectors described recently (Follenzi et al., 2000). To simultaneously transduce both the reporter and target gene, a new lentiviral vector, Tween, was generated by engineering pRRLsin.cPPT.hCMV.GFP.Wpre. In this vector, the hCMV.GFP cassette was substituted with hCMV.hPGK.GFP. A multiple cloning site was inserted downstream of hCMV (human cytomegalovirus). mGlu4 receptor cDNA was subcloned in the XbaI site of the Tween vector. Lentiviral supernatants were produced by calcium phosphate transient cotransfection of a three-plasmid expression system in HEK 293 cells. The calcium-phosphate DNA precipitate was removed after $14-16 \mathrm{hr}$ by replacing the medium. The viral supernatant was collected $48 \mathrm{hr}$ after transfection, filtered through 0.45 $\mu \mathrm{m}$ pore nitrocellulose filters, and frozen in liquid nitrogen. Polybrene (4 $\mu \mathrm{g} / \mathrm{ml}$ ) was added to the viral supernatant to improve the infection efficiency (Follenzi et al., 2000). On the same day of transfection, rat cerebellar granule cells were plated in BME containing 10\% FCS and incubated for $2 \mathrm{hr}$. Afterward, the medium was replaced with the viral supernatants, and plates were centrifuged for $20 \mathrm{~min}$ at low speed and left with the viral medium for $4 \mathrm{hr}$. Cells were then returned to their initial conditioned medium and maintained in the incubator for additional $18 \mathrm{hr}$.

Measurement of neurite length. Bright-field images of neurons were obtained using an IX 50 microscope (Olympus, Tokyo, Japan) in a blinded manner. Digitized images were obtained using a SPOT-RT television camera (sensor resolution, $1520 \times 1080$ pixels; CCD element, $7.4 \times 7.4 \mu \mathrm{m}$; Diagnostic Instruments, Sterling Heights, MI). All images were acquired during one session, using the same brightness setting. Neurites were measured in four random microscopic fields per dish. Neurites were selected for measurement only when they had an obvious attachment to the neuronal soma. If neurites forked, only the longest branch was measured. Digitized images were calibrated with a commercial calibration slide for a $20 \times$ objective, which allowed measurement of neurites in millimeters.

TUJ1 staining. Cultures were fixed in $4 \%$ paraformaldehyde for 15 min. After blocking with $4 \%$ normal goat serum for $1 \mathrm{hr}$, incubation with the primary antibody (monoclonal antibody against neuronal class III $\beta$-tubulin; clone TUJ1; 1:100; Covance, San Diego, CA) was performed overnight. Immunostaining was revealed by the avidin-biotin-peroxidase method.

Assessment of cell toxicity. Apoptotic death in cultured cerebellar granule cells was measured as described previously (Melchiorri et al., 2001). Cerebellar granule cells were cultured in $35 \mathrm{~mm}$ dishes, and chromatin 
a

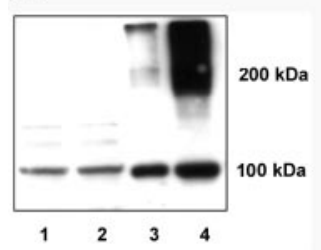

b

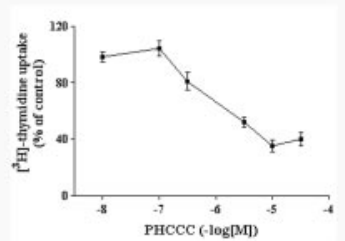

c

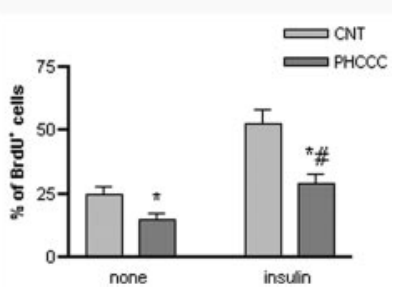

Figure 1. a, Immunoblots of mGlu4 receptors in rat cerebellar cultures plated in CDM (lane 1), BME (lane 2), and BME plus 10\% FCS (lane 3). The adult rat cerebellum (lane 4) is shown as a positive control. Immunoreactive bands corresponding to monomeric mGlu4 receptor are at $\sim 100 \mathrm{kDa}$. These bands were absent in the cerebellum of mGlu4 knock-out mice (data not shown). $b$, Concentration-dependent inhibition of [ $\left.{ }^{3} \mathrm{H}\right]$ thymidine incorporation by PHCCC ( $24 \mathrm{hr}$ of exposure) in cultures of rat cerebellar granule cells. Values are means \pm SEM of six determinations from two independent experiments. C, PHCCC reduced the number of BrdU ${ }^{+}$GNPs in rat cerebellar cultures. BrdU ${ }^{+}$cells were counted in four microscopic fields from 12 culture dishes from three independent experiments by an observer who was unaware of the treatment. Values are means \pm SEM. $p<0.05$ (1-way ANOVA plus Fisher's PLSD) versus the corresponding values in the absence of $\mathrm{PHCCC}\left({ }^{*}\right)$ or versus PHCCC alone (\#).

Table 1. Influence of subtype-selective $\mathrm{mGlu}$ receptor ligands on $\left[{ }^{3} \mathrm{H}\right]$ thymidine incorporation in immature cultured granule cells

\begin{tabular}{|c|c|c|c|}
\hline & {$\left[{ }^{3} \mathrm{H}\right]$ thymidi } & $\mathrm{n} /$ dish) $\times 10^{-}$ & \\
\hline & & $\mathrm{PHCCC}$ & \\
\hline & None & $3 \mu \mathrm{M}$ & $30 \mu \mathrm{M}$ \\
\hline Control & $366 \pm 8$ & $276 \pm 5^{a}$ & $96 \pm 6^{a}$ \\
\hline MSOP $(200 \mu \mathrm{M})$ & $457 \pm 12^{b}$ & $358 \pm 14^{a, b}$ & $244 \pm 31^{a, b}$ \\
\hline MSOP (1 mм) & $422 \pm 6^{b}$ & ND & $233 \pm 19^{a, b}$ \\
\hline MPPG (1 mм) & $375 \pm 32$ & $315 \pm 9^{a, b}$ & $194 \pm 36^{a, b}$ \\
\hline $\operatorname{MPEP}(0.1 \mu \mathrm{M})$ & $329 \pm 25$ & $250 \pm 14^{a}$ & $88 \pm 6^{a}$ \\
\hline CPCCOEt (10 $\mu \mathrm{M})$ & $380 \pm 26$ & $261 \pm 20^{a}$ & $84 \pm 12^{a}$ \\
\hline LY367385 (10 $\mu \mathrm{m})$ & $370 \pm 7$ & ND & $101 \pm 21^{a}$ \\
\hline LY379268 (0.1 $\mu \mathrm{M})$ & $390 \pm 8$ & ND & $92 \pm 15^{a}$ \\
\hline LY341495 (0.1 $\mu \mathrm{M})$ & $360 \pm 15$ & $276 \pm 22^{a}$ & $82 \pm 10^{a}$ \\
\hline
\end{tabular}

Cultures were exposed to drugs for $24 \mathrm{hr}$. mGlu receptor ligands were applied $10 \mathrm{~min}$ before PHCCC. Values are means \pm SEM of six to nine determinations from two to three independent experiments. $p<0.05$ (1-way ANOVA plus Fisher's PLSD) versus the respective values in the absence of PHCCC (None) ( $\left.{ }^{a}\right)$ or the respective control values $\left({ }^{b}\right)$. ND, Not determined.

Table 2. Inhibition of $\left[{ }^{3} \mathrm{H}\right]$ thymidine incorporation in cultured cerebellar granule cells grown for $24 \mathrm{hr}$ under different conditions

\begin{tabular}{|c|c|c|c|}
\hline & \multicolumn{3}{|c|}{$\left[{ }^{3} \mathrm{H}\right]$ thymidine incorporation (dpm/dish) $\times 10^{-3}$} \\
\hline & BME & $\begin{array}{l}\text { BME plus } \\
10 \% \text { FCS }\end{array}$ & CDM \\
\hline Control & $482 \pm 18$ & $864 \pm 5$ & $1324 \pm 16$ \\
\hline $\mathrm{PHCCC}(30 \mu \mathrm{M})$ & $194 \pm 36^{a}$ & $508 \pm 19^{a}$ & $416 \pm 16^{a}$ \\
\hline Insulin $(0.5 \mathrm{mg} / \mathrm{ml})$ & $756 \pm 4$ & $1190 \pm 7$ & $1588 \pm 73$ \\
\hline Insulin plus PHCCC & $466 \pm 44^{a, b}$ & $588 \pm 14^{a}$ & $418 \pm 20^{\circ}$ \\
\hline SHH $(2 \mu \mathrm{g} / \mathrm{ml})$ & $616 \pm 24$ & ND & ND \\
\hline SHH plus PHCCC & $182 \pm 3^{a}$ & ND & ND \\
\hline
\end{tabular}

Values are means of $9-12$ determinations from three to four independent experiments. $p<0.05$ (1-way ANOVA plus Fisher's PLSD) compared with the corresponding values obtained in the absence of PHCCC $\left({ }^{a}\right)$ or with values obtained with PHCCC alone $\left.{ }^{b}\right)$. ND, Not determined.

fragmentation and condensation, two hallmark features of apoptotic death, were visualized by staining the cells with the fluorescent dye Hoechst $33258(0.4 \mu \mathrm{g} / \mathrm{ml})$. Apoptotic neurons were scored from four random fields per dish in at least four individual dishes for experimental conditions. LDH release, an index of cell damage, was assessed using a commercial kit (Roche). Absorbance data were read using a 96-well plate reader with a $490 \mathrm{~nm}$ filter. Maximum release was obtained by incubating the cells with $0.5 \%$ Triton X for $24 \mathrm{hr}$.

Western blot analysis. Western blot analysis was performed as described previously (Iacovelli et al., 2002). Briefly, for the detection of the phosphorylated forms of mitogen-activated protein kinase (MAPK) and AKT, cerebellar granule cells seeded at a density of $2 \times 10^{6}$ cells/well were serum starved for $1 \mathrm{hr}$ and then challenged with drugs for $10 \mathrm{~min}$ at $37^{\circ} \mathrm{C}$. Reaction was stopped by washing twice with ice-cold PBS, and cells were lysed for $10 \mathrm{~min}$ at $4^{\circ} \mathrm{C}$ in Triton X lysis buffer (10 mM Tris-HCl, $\mathrm{pH}$ 7.4,
$150 \mathrm{~mm} \mathrm{NaCl}, 1 \%$ Triton X-100, 1 mм EDTA, $10 \%$ glycerol, $1 \mathrm{~mm}$ phenylmethylsulfonyl fluoride, $10 \mu \mathrm{g} / \mathrm{ml}$ leupeptin, $10 \mu \mathrm{g} / \mathrm{ml}$ aprotinin, $1 \mathrm{~mm}$ sodium orthovanadate, $50 \mathrm{~mm}$ sodium fluoride, and $10 \mathrm{~mm} \beta$-glycerophosphate).

For the detection of Gli-1 protein, granule cells were suspended at a density of $2 \times 10^{6}$ cells $/ \mathrm{ml}$ into $2 \mathrm{ml}$ of BME without serum and incubated at $37^{\circ} \mathrm{C}$ for $30 \mathrm{~min}$ with PHCCC (30 $\mu \mathrm{M})$, forskolin $(10 \mu \mathrm{M})$, or a combination of forskolin and PHCCC. Thereafter, cells were lysed using the same lysis buffer described above. All cell lysates were cleared by centrifugation $(10,000 \times g$ for $10 \mathrm{~min})$, and $80 \mu \mathrm{g}$ of proteins was separated by SDS-gel electrophoresis, blotted onto nitrocellulose, and probed using different commercial antibodies. Membranes were saturated for $1 \mathrm{hr}$ with Trisbuffered saline (100 mm Tris and $0.9 \% \mathrm{NaCl}$ ) containing $0.05 \%$ Tween $20,1 \%$ bovine serum albumin, and $1 \%$ nonfat dry milk and then incubated overnight with primary antibodies. For the detection of mGlu4 receptors, we followed the same procedure as described previously (Iacovelli et al., 2004). Antibodies were used at the following dilutions: monoclonal antiphospho-ERK1/2 (1:1000; Cell Signaling Technology); polyclonal anti-phospho-AKT (1:500; Cell Signaling Technology); polyclonal anti-Gli-1 (1:200; Santa Cruz Biotechnology); polyclonal anti-ERK1/2 (1:2000; Santa Cruz Biotechnology); monoclonal anti-AKT (1:1000; Cell Signaling Technology); polyclonal anti-mGlu4 receptor (1: 500; Upstate Biotechnology); monoclonal anti$\beta$-actin (1:2000; Sigma-Aldrich). The immunoreactive bands were visualized by enhanced chemiluminescence using horseradish peroxidaselinked secondary antibody.

cAMP assay. Cultured cerebellar granule cells at 4 or $24 \mathrm{hr}$ after plating were incubated for 20 min in Krebs-Heinslet buffer or, alternatively, in their growing medium. Experiments were always performed in the presence of 0.5 $\mathrm{mm}$ isobutylmethylxanthine. The reaction was stopped by adding $1 \mathrm{vol}$ of $0.8 \mathrm{~N} \mathrm{HClO}_{4}$. The samples were kept frozen or used immediately. After neutralization with $2 \mathrm{M} \mathrm{K}_{2} \mathrm{CO}_{3}$, the intracellular content of cAMP of each sample was determined using a commercial radioimmunoassay kit (Amersham, Milan, Italy).

Reverse transcription-PCR analysis. Reverse transcription (RT)-PCR analysis in PC12 and U87MG cells was performed as described previously (Iacovelli et al., 2002). Amplification of mGlu4 receptor cDNA was performed using the following primers: forward, CCAACGAGGATGACATCAGG; reverse, ACACAGGTCACGGTGCATGG. PCR products were analyzed electrophoretically on a $2 \%$ agarose gel poured and run in $1 \times$ Trisacetate EDTA buffer.

In vivo experiments. Different groups of rats at postnatal day 3 (P3) were treated with PHCCC (dissolved in a vehicle containing $0.6 \% 5 \mathrm{~N}$ $\mathrm{NaOH}$ and $1 \%$ DMSO and buffered with $\mathrm{NaH}_{2} \mathrm{PO}_{4}$ ) either systemically $(5 \mathrm{mg} / \mathrm{kg}$, i.p.) or intracerebrally ( $5 \mathrm{nmol} / 2 \mu \mathrm{l} / 2 \mathrm{~min}$; injected through the scalp in the posterior region of the cerebellum, $2-3 \mathrm{~mm}$ posterior to $\lambda$, under conditions of deep hypothermia). Control animals received injections of vehicle. Systemic injections were performed once per day, whereas intracerebral injections were performed every other day up to $\mathrm{P} 9 / 10$. On the seventh day of systemic injections, animals were divided into two groups. One group received three injections of $20 \mathrm{mg} / \mathrm{kg} \mathrm{BrdU}$ 
at $1.5 \mathrm{hr}$ intervals and was killed the next day. The second group was allowed to survive free of drugs up to P19 and thereafter injected with $\mathrm{BrdU}$ on P20 and killed at P21. All rats given intracerebral injections were killed at P10. Brains were dissected, and the cerebella were collected and weighted. Soon after, cerebella were fixed in Carnoy solution for $16 \mathrm{hr}$ at $4^{\circ} \mathrm{C}$. On the following day, cerebella were treated with $70 \%$ ethanol solution, included in paraffin, and processed for morphological and immunohistochemical analysis using monoclonal BrdU antibody (1:20 dilution; Becton Dickinson). Nissl staining and calbindin immunostaining was performed as described previously (Catania et al., 2001).

\section{Results}

We examined whether activation of mGlu4 receptors could influence the proliferation and differentiation of GNPs using purified cerebellar cultures prepared from 5- to 6-d-old rats, and plated under different growing conditions. Cultures expressed the mGlu4 receptor protein $24 \mathrm{hr}$ after plating (Fig. 1a). Initial experiments were performed in cultures plated in BME-lacking serum. Extracellular glutamate concentrations were $2.15 \pm 0.32$ $\mu \mathrm{M}(n=5) 1 \mathrm{~d}$ after plating. These concentrations are sufficient to activate mGlu4 receptors (Schoepp et al., 1999). The number of $\mathrm{BrdU}^{+}$GNPs in control cultures ranged from 23 to $32 \%$ of the total cell population, as assessed by immunocytochemistry. Contaminating astrocytes that might incorporate $\mathrm{BrdU}^{+}$were always $<1 \%$, as detected by GFAP immunostaining (data not shown). The group III mGlu receptor agonist L-AP-4 (30 $\mu \mathrm{M})$, applied since the time of plating, induced only a slight reduction of $\left[{ }^{3} \mathrm{H}\right]$ thymidine incorporation after $24 \mathrm{hr}(310,000$ plus 26,000 and 240,000 plus 18,000 dpm/well in control and L-AP-treated cultures, respectively; $n=6 ; p<0.05$, Student's $t$ test). Because $\mathrm{L}-\mathrm{AP}-4$ is not subtype selective and competes with endogenous glutamate at the receptor binding site, we decided to use the novel compound PHCCC, which acts as a selective positive modulator of mGlu4 receptors (Maj et al., 2003). PHCCC added to the cultures substantially reduced $\left[{ }^{3} \mathrm{H}\right]$ thymidine incorporation (Fig. $1 b$ ) and lowered the number of $\mathrm{BrdU}^{+}$cells (Fig. 1c). PHCCC acted in a concentration range similar to that reported for the positive modulation of mGlu4 receptors (Maj et al., 2003), producing a maximal inhibition of $\left[{ }^{3} \mathrm{H}\right]$ thymidine incorporation at $10 \mu \mathrm{M}$ (Fig. 1b). The action of PHCCC was not enhanced by the coapplication of L-AP-4 (data not shown), but it was attenuated, albeit slightly, by the mGlu4 receptor antagonists MSOP and MPPG (Table 1), suggesting that the drug maximally amplified the stimulation of mGlu4 receptors by the endogenous glutamate. Ligands of other mGlu receptor subtypes, including the

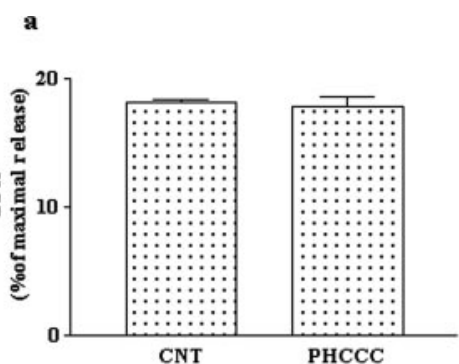

b

\begin{tabular}{|c|c|c|c|}
\hline & TOTAL CELL NUMBER & $\begin{array}{c}\text { APOPTOTIC CELL } \\
\text { NUMBER }\end{array}$ & $\begin{array}{c}\text { \% OF APOPTOTIC } \\
\text { CELLS }\end{array}$ \\
\hline BASAL & $468 \pm 28$ & $99 \pm 15.5$ & $21 \pm 3.1$ \\
\hline PHCCC & $518 \pm 19$ & $78 \pm 8.2$ & $15.3 \pm 2.3$ \\
\hline
\end{tabular}

Figure 2. A 24 hr exposure to PHCCC was not toxic to cultured granule cells. Toxicity was assessed by measuring LDH release $(a)$ and Hoechst chromatin staining $(b)$. Values are means \pm SEM of six to nine determinations from two to three independent experiments.
Table 3. Inhibition of $\left[{ }^{3} \mathrm{H}\right]$ thymidine incorporation by PHCCC in cultured cerebellar granule cells from wild-type and mGlu4-/ - mice

\begin{tabular}{lll}
\hline & {$\left[{ }^{3} \mathrm{H}\right]$ thymidine incorporation (dpm/dish) $\times 10^{-3}$} \\
\cline { 2 - 3 } & Wild type & mGlu4-/- \\
\hline BME & & \\
$\quad$ Control & $260 \pm 34$ & $245 \pm 9$ \\
$\quad$ PHCCC $(10 \mu \mathrm{M})$ & $174 \pm 7^{*}(-33 \%)$ & $224 \pm 16(-8 \%)$ \\
BME plus $10 \% \mathrm{FCS}$ & & \\
$\quad$ Control & $336 \pm 19$ & $380 \pm 35$ \\
PHCCC $(10 \mu \mathrm{M})$ & $210 \pm 12^{*}(-37 \%)$ & $392 \pm 15(+3 \%)$ \\
\hline
\end{tabular}

Cells from wild-type or knock-out mice were plated at the same density $\left(1.5 \times 10^{6}\right.$ cells per $35 \mathrm{~mm}$ culture dish), and cultures were exposed to PHCCC for $24 \mathrm{hr}$. Values are means \pm SEM of six determinations from two independent experiments.

" $p<0.05$ (Student's $t$ test) versus the respective controls.

\section{a}

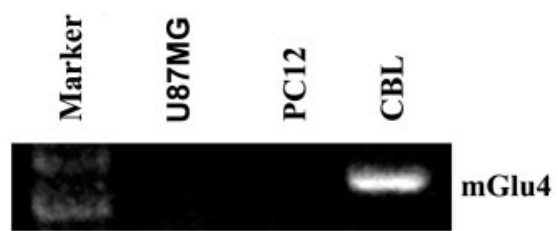

b

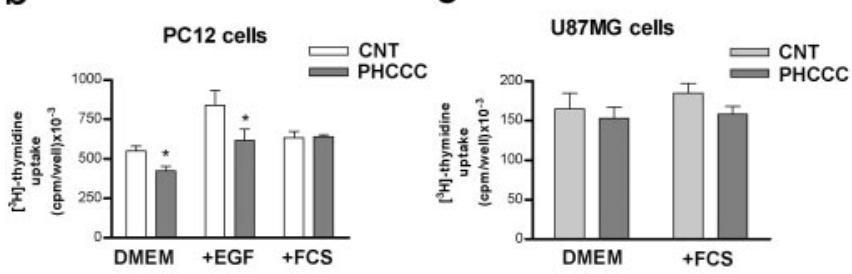

d

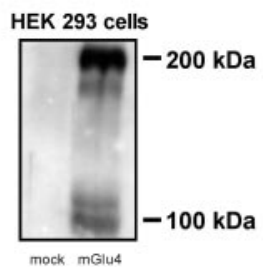

e

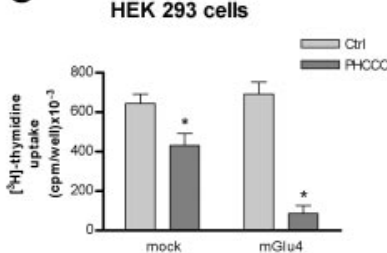

Figure 3. $a, \mathrm{RT}-\mathrm{PCR}$ analysis of mGlu4 receptor $\mathrm{mRNA}$ in $\mathrm{PC} 12$ and U87MG cells; the rat cerebellum is shown as a positive control. $b$, Effect of a $24 \mathrm{hr}$ exposure to $\mathrm{PHCCC}$ on $\left[{ }^{3} \mathrm{H}\right]$ thymidine incorporation in PC12 cells. Values are means \pm SEM of 12-15 determinations from four to five independent experiments. ${ }^{*} p<0.05$ (Student's $t$ test) compared with control (CNT) cultures. C, Effect of a $24 \mathrm{hr}$ exposure to PHCCC on [ $\left.{ }^{3} \mathrm{H}\right]$ thymidine incorporation in cultured U87MG cells. Values are means + SEM of six determinations from two independent experiments. $d$, Immunoblot of mGlu4 receptors in cultured HEK 293 cells transfected with the empty vector (mock) or with mGlu4 receptor CDNA. e, Effect of a $24 \mathrm{hr}$ exposure to $\mathrm{PHCCC}$ on $\left[{ }^{3} \mathrm{H}\right]$ thymidine incorporation in mock or mGlu4 receptor expressing HEK 293 cells. Values are means + SEM of six determinations from two independent experiments. ${ }^{*} p<0.05$ (Student's $t$ test) compared with control (Ctrl) cultures.

mGlu1 receptor antagonist CPCCOEt $(10 \mu \mathrm{M}$; a restricted structural analog of PHCCC), the mGlu5 receptor antagonist MPEP $(1 \mu \mathrm{M})$, the mGlu2/3 receptor agonist LY379268 (100 nM), and the mGlu2/3 receptor antagonist LY341495 (100 nM), had no effect per se and did not affect the reduction of $\left[{ }^{3} \mathrm{H}\right]$ thymidine incorporation induced by PHCCC in immature cultured granule cells (Table 1). The efficacy of PHCCC in reducing $\left[{ }^{3} \mathrm{H}\right]$ thymidine incorporation varied in relation to the growth conditions. In control cultures and in cultures stimulated with insulin, PHCCC was more efficacious when cells were plated in CDM than in BME (with or without serum). In addition, when BME was used as a growing medium, PHCCC reduced $\left[{ }^{3} \mathrm{H}\right]$ thymidine incorporation to a much greater extent in cultures stimulated with $\mathrm{SHH}$ 


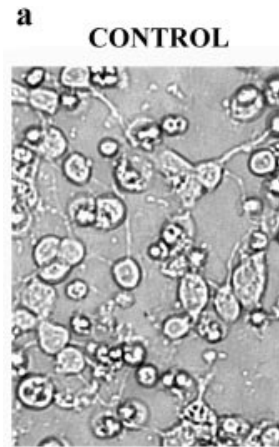

c

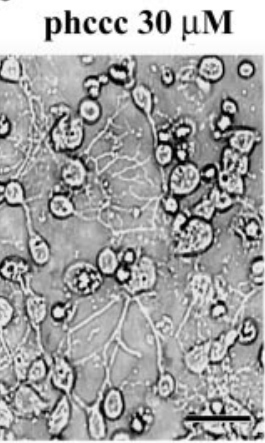

b

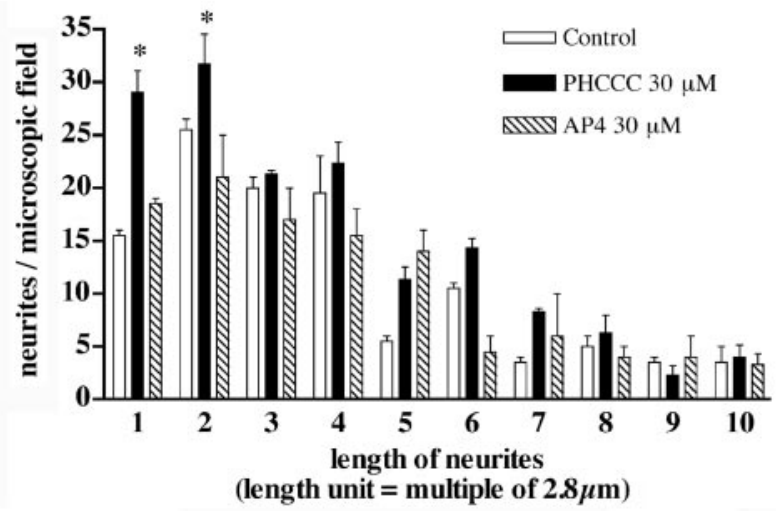

d

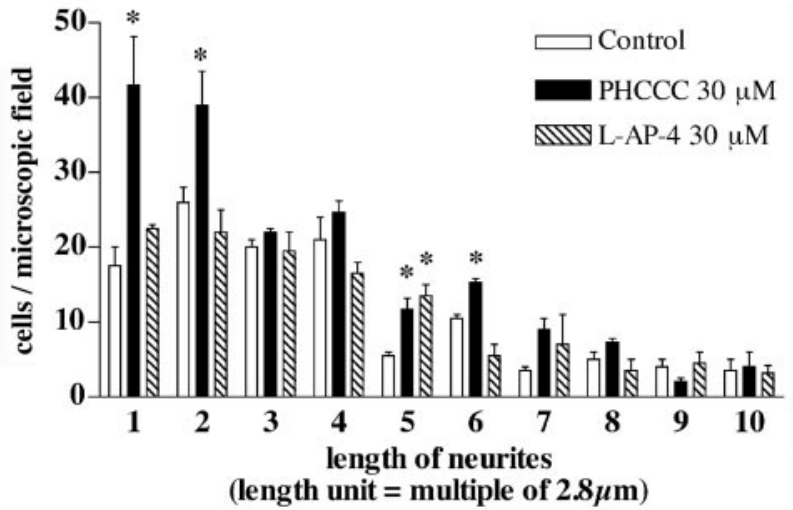

Figure 4. A $24 \mathrm{hr}$ exposure to $\mathrm{PHCCC}$ promotes neurite growth in cultured granule cells. Phase- contrast microphotographs of control cultures and cultures treated with $30 \mu \mathrm{M} \mathrm{PHCCC}$ are shown in $a$ and $b$. The number of neurites of different length per microscopic field in control cultures and in cultures treated with PHCCC or L-AP-4 (both at $30 \mu \mathrm{m}$ ) is reported in c; the number of treated cells bearing neurites of different length is shown in $d$. Values are means \pm SEM of six determinations from two independent experiment. Each value is the mean of determinations obtained from four microscopic fields/dish by an observer who was unaware of the treatment. ${ }^{*} p<0.05$ (1-way ANOVA plus Fisher's PLSD) versus the respective controls. Scale bar, $20 \mu \mathrm{m}$.

than in cultures stimulated with insulin (Table 2). Interestingly, insulin was still able to stimulate $\left[{ }^{3} \mathrm{H}\right]$ thymidine incorporation in PHCCC-treated cultures grown in BME alone (compare PHCCC with insulin plus PHCCC in Table 2 and in Fig. $1 c$ for $\mathrm{BrdU}^{+}$ staining), but not in cultures grown in BME plus $10 \%$ FCS or in CDM (Table 2). The lowering effect of PHCCC on $\left[{ }^{3} \mathrm{H}\right]$ thymidine incorporation was not a consequence of cell toxicity because no increases in $\mathrm{LDH}$ release or in the number of cells harboring chromatin fragmentation or nuclear pyknosis were detected in serum-free cultures exposed to $30 \mu \mathrm{M}$ PHCCC for $24 \mathrm{hr}$ (Fig. 2). The lack of toxicity was confirmed in cultures grown in BME with $10 \%$ FCS and exposed to PHCCC for $48 \mathrm{hr}$ (percentage of apoptotic neurons, $15 \pm 3.5$ and $12 \pm 2.9$ in control cultures and in cultures exposed to $30 \mu \mathrm{M}$ PHCCC, respectively; Hoechst 33258 staining, $n=5$ ). To examine whether activation of $\mathrm{mGlu} 4$ receptors was critical for the antiproliferative effect of PHCCC, we studied $\left[{ }^{3} \mathrm{H}\right]$ thymidine incorporation in cultured granule cells prepared from wild-type or $\mathrm{mGlu} 4$ receptor knock-out mice. The percentage of $\mathrm{BrdU}^{+}$cells (counted after $24 \mathrm{hr}$ ) was $18 \pm 4.1$ and $22 \pm 5.6$ in cultures prepared from wild-type and mGlu4-/mice, respectively $(n=4)$. Exposure to saturating concentrations of PHCCC $(10 \mu \mathrm{M})$ reduced $\left[{ }^{3} \mathrm{H}\right]$ thymidine incorporation in wild-type cultures to an extent similar to that observed in rat cultures. In contrast, PHCCC was virtually inactive in mGlu4-/- cultures (Table 3 ). We also examined the effect of PHCCC on $\left[{ }^{3} \mathrm{H}\right]$ thymidine incorporation in other cell types that do not express detectable amounts of mGlu4 receptors (Fig. $3 a$ ). Cultured undifferentiated PC12 cells were starved for $24 \mathrm{hr}$ and then treated with DMEM alone, DMEM containing $10 \mathrm{ng} / \mathrm{ml} \mathrm{EGF,} \mathrm{or}$ DMEM containing 10\% FCS. A $24 \mathrm{hr}$ exposure to PHCCC (30 $\mu \mathrm{M})$ had no affect in cultures stimulated with $10 \%$ FCS but induced a slight (but significant) reduction in $\left[{ }^{3} \mathrm{H}\right]$ thymidine incorporation in unstimulated cells or in cells treated with EGF (Fig. 3b). PHCCC did not affect proliferation of U87MG glioma cells (starved for $48 \mathrm{hr}$ and then incubated for $24 \mathrm{hr}$ with $30 \mu \mathrm{M}$ PHCCC applied alone or combined with 10\% FCS) (Fig. 3c). We extended the study to HEK 293 cells transiently transfected with mGlu4 receptor cDNA. In cells transfected with an empty vector (mock), which did not express a detectable amount of the mGlu4 receptor protein (Fig. $3 d$ ), PHCCC $(30 \mu \mathrm{M})$ reduced $\left[{ }^{3} \mathrm{H}\right]$ thymidine incorporation by $\sim 32 \%$ (Fig. $3 e$ ). However, in cells expressing mGlu4 receptors, PHCCC showed a much greater efficacy, reducing $\left[{ }^{3} \mathrm{H}\right]$ thymidine incorporation by $>85 \%$ (Fig. $3 e$ ).

We performed a microscopic analysis of cultured granule cells to examine whether cell cycle inhibition was associated with changes in cell differentiation and neuritogenesis after a $24 \mathrm{hr}$ exposure to PHCCC. Drug treatment increased the total number of neurites with a length $<8.24 \mu \mathrm{m}$ as well as the number of cells bearing small neurites. PHCCC did not affect the number of longer neurites. L-AP-4 had virtually no effect on neurite length (Fig. $4 a-d$ ). The differentiating effect of PHCCC was confirmed by a microscopic analysis of cells expressing the specific neuronal marker TUJ1. A $24 \mathrm{hr}$ exposure to $30 \mu \mathrm{M}$ PHCCC increased the percentage of TUJ1expressing cells in cultures grown in BME (Fig. $5 a-c$ ). To assess the role of mGlu4 receptors on neuritogenesis more directly, we infected the cultures with a lentiviral vector encoding both the mGlu4 receptors and green fluorescent protein (GFP). This particular experiment was performed in cultures grown in BME containing 10\% FCS. Approximately $15-20 \%$ of cells were infected, as shown by GFP staining (Fig. $6 a$ ). Infected cultures overexpressed the $\mathrm{mGlu} 4$ receptor protein, as shown by the representative immunoblot in Figure $6 b$. The number of neurites was substantially enhanced in cultures overexpressing mGlu4 receptors (Fig. 6c-e).

Searching for a transduction pathway that could mediate the biological effects of PHCCC on GNPs, we first focused on the inhibition of adenylyl cyclase, which is the canonical pathway associated with mGlu4 receptor activation. PHCCC significantly reduced the increase in cAMP formation induced by forskolin both in cells stimulated in their growing medium and in cells incubated in Krebs-Henseleit buffer (Fig. $7 a$ and data not shown). This is similar to what was reported in recombinant cells expressing mGlu4 receptors (Maj et al., 2003). PHCCC had no effect on basal cAMP formation under any experimental conditions at both 4 and $24 \mathrm{hr}$ after plating (Fig. $7 a$ and data not 
shown). A $24 \mathrm{hr}$ exposure to forskolin (10 $\mu \mathrm{M})$ slightly attenuated the lowering effect of PHCCC on $\left[{ }^{3} \mathrm{H}\right]$ thymidine incorporation in cultured granule cells, although the cell permeant cAMP analog 8Br-cAMP (1 $\mathrm{mM}$ ) was inactive (Table 4). This suggests that inhibition of cAMP formation plays a minor role, if any, in the antiproliferative effect of PHCCC (Table 4). We extended the analysis to other pathways or factors that are known to regulate cell proliferation, including the MAPK pathway, the phosphatidylinositol-3-kinase (PI-3-K) pathway, and the transcription factor Gli-1. As expected, insulin activated both the MAPK and the PI-3-K pathways, as shown by an increase in the levels of phosphorylated ERK1/2 and phosphorylated AKT, respectively (Fig. $7 b, c$ ). PHCCC (30 $\mu \mathrm{M})$ did not affect the basal- and insulinstimulated activity of both pathways but reduced the slight increase in phosphorylated AKT induced by forskolin (Fig. 7b). We also examined the action of PHCCC in the presence of LY294002 (10 $\mu \mathrm{M})$, which mostly reduced insulin-stimulated PI-3-K activation (Fig. 1b), and UO126 (10 $\mu \mathrm{M})$, which slightly reduced basal phosphoERK1/2 levels and more substantially reduced activation of the MAPK pathway by insulin (Fig. 7c) A $24 \mathrm{hr}$ exposure to UO126 produced only a small reduction in $\left[{ }^{3} \mathrm{H}\right]$ thymidine incorporation in cultured granule cells, whereas larger reductions were produced by LY294002. Inhibition of $\left[{ }^{3} \mathrm{H}\right]$ thymidine incorporation by PHCCC was still substantial in the presence of LY294002 or UO126 (Table 4), suggesting (but not proving) that the MAPK and PI-3-K pathways are not critical for the antiproliferative action of $\mathrm{PH}$ CCC. We also examined the expression of the full-length variant of the transcription factor Gli-1, which is known to mediate the mitogenic effects of SHH on granule cell precursors. A 30 min exposure to $\mathrm{PH}$ CCC decreased the levels of full-length Gli-1 (Fig. $7 d$ ), suggesting a potential interaction between mGlu4 receptors and the SHH-Patched-Smoothened pathway.

We also performed in vivo experiments in which PHCCC was injected either intraperitoneally ( $5 \mathrm{mg} / \mathrm{kg} / \mathrm{d}$ ) or intracerebrally ( 5 $\mathrm{nmol} / 2 \mu \mathrm{l}$ infused for $2 \mathrm{~min}$ in the cerebellar region every other day) to pups from P3 to P9. In animals infused with PHCCC in the cerebellar region (all examined at P10), the treatment induced substantial changes in the morphology of the developing cerebellum. Nissl staining showed a marked cell reduction in the internal granular layer (Fig. 8a,b), and calbindin immunostaining showed abnormalities in the dendritic tree of Purkinje cells (Fig. $8 c, d$ ). Animals at P10 treated intraperitoneally with PHCCC did not show substantial changes in the morphology of the developing cerebellum and in the number of $\mathrm{BrdU}^{+}$cells counted in the molecular/Purkinje cell and internal granular layers of the cerebellar cortex (data not shown). The thickness of the external granular layer was also similar between controls and PHCCC-treated rats $\left(\mathrm{BrdU}^{+}\right.$cells in this layer were too tightly packed to be counted reliably). However, $11 \mathrm{~d}$ after the end of the treatment (i.e., at P21), the weight of the cerebellum was consistently lower $(-27 \%)$ in rats treated intraperitoneally with PHCCC (Table 5). Although no changes in the gross anatomy of the cerebellum were present, we noted abnormalities in the morphology of lobule $\mathrm{V}$ in four of the six animals treated with PHCCC. In these animals, we did not observe the typical projections of the internal granular layer present in the mature lobule $\mathrm{V}$ of all control animals (Fig. 9), suggesting a diminished development of this layer. 
a

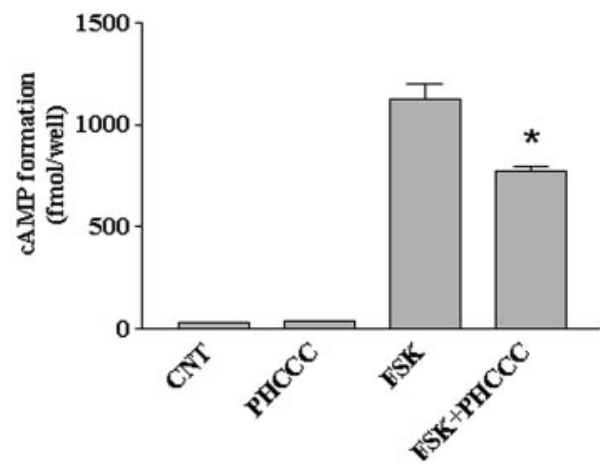

b
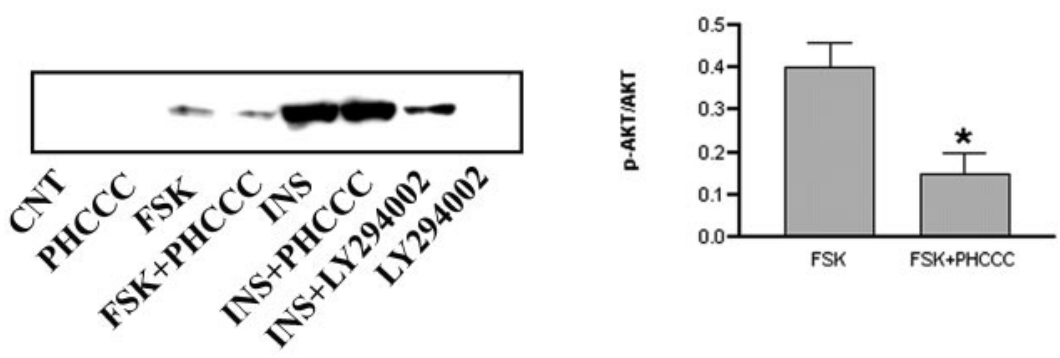

c

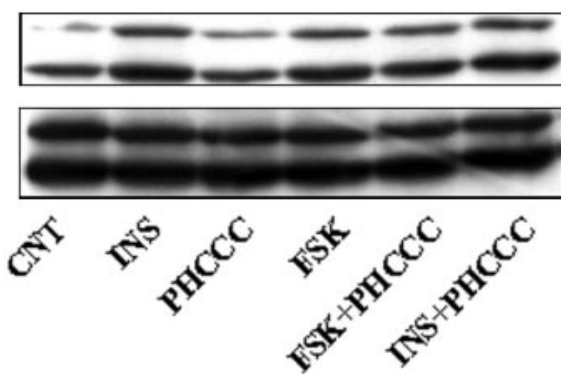

p- ERK1

p- ERK2

ERK1

ERK2

d

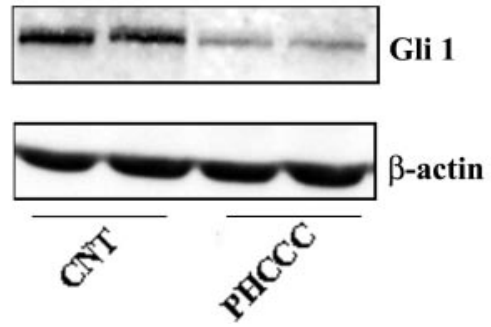

Figure 7. a, PHCCC reduces forskolin-stimulated CAMP formation in cultured granule cells. The Figure refers to data obtained in cultures incubated in Krebs-Henseleit buffer. Similar results were obtained in cultures incubated in their growing medium (BME alone) both at 4 and $24 \mathrm{hr}$ after plating (data not shown). Under no conditions was PHCCC able to reduce basal cAMP formation. CNT, Control; PHCCC, $30 \mu \mathrm{m}$; forskolin, $10 \mu \mathrm{m}$; values are means \pm SEM of six determinations. ${ }^{*} p<0.05$ (1-way ANOVA plus Fisher's PLSD) versus forskolin alone. $b$, Western blot analysis of phosphorylated AKT in cultures plated in BME alone and treated for $10 \mathrm{~min}$ with the indicated drugs. CNT, Control; forskolin $(10 \mu \mathrm{M})$; insulin $(0.5 \mathrm{mg} / \mathrm{ml})$; LY294002 (10 $\mu \mathrm{M})$ was applied $30 \mathrm{~min}$ before insulin. Densitometric analysis of values obtained with forskolin alone and forskolin plus $\operatorname{PHCCC}(n=4)$ are also shown. Values (normalized by the expression of nonphosphorylated AKT) are means \pm SEM. ${ }^{*} p<0.05$ (Student's $t$ test) versus forskolin alone. Representative immunoblots of phosphorylated and nonphosphorylated ERK $1 / 2$ in cultures challenged with the indicated drugs are shown in c. Incubation times and concentrations are the same as in $b . \mathrm{UO}, \mathrm{U} 0126(10 \mu \mathrm{M})$. Note that PHCCC was unable to affect the MAPK pathway and that U0126 slightly reduced the basal levels of phosphorylated ERK1/2 and more substantially reduced the activation of the MAPK pathway by insulin. Blots were repeated three times with similar results. Expression of the transcription factor Gli-1 in granule cells treated with PHCCC (30 $\mu \mathrm{m})$ for $30 \mathrm{~min}$ is shown in d. CNT, Control. A reduced expression of Gli-1 was consistently seen in four additional samples per group.

\section{Discussion}

The process of granule cell differentiation undergoes a finely tuned regulation, which is essential for the proper matching and synapse formation among neurons of the cerebellar cortex. GNPs proliferate in the external granular layer in response to a variety of signals, including IGF-I (DiCicco-Bloom and Black, 1989; Gao et al., 1991; Ye et al., 1996; Lin and Bulleit, 1997) and SHH (Altman and Bayer, 1996; Dahmane and Ruiz-i-Altaba, 1999; Wallace, 1999; Wechsler-Reya and Scott, 1999). The signals that arrest GNP proliferation and promote their differentiation into granule cells are only partially identified. PACAP, a neuropeptide produced by Purkinje cells (Nielsen et al., 1998; Skoglosa et al., 1999), potently inhibits GNP proliferation induced by $\mathrm{SHH}$ but slightly increases DNA synthesis when applied alone or in the presence of insulin (Nicot et al., 2002). Our results show that an amplified activity of mGlu4 receptors inhibits DNA synthesis in GNP-containing cultures. The study of glutamate receptors in these cultures is biased by the presence of endogenous glutamate, which masks the effects of exogenous receptor agonists. This may explain why we found only small effects with L-AP-4, a prototypic mGlu4 receptor agonist that competes with glutamate at the receptor binding site (for review, see Schoepp et al., 1999). We could explore receptor function using PHCCC, a selective mGlu4 receptor enhancer, which interacts with an allosteric site located in the 7-TM region of the receptor (Maj et al., 2003). PHCCC selectively amplifies mGlu4 receptor activity in the concentration range used in our experiments (Maj et al., 2003), but it can recruit mGlu1 receptors at higher concentrations. At 30 $\mu \mathrm{M}, \mathrm{PHCCC}$ reduces $\mathrm{mGlul}$ receptor activity by 30\% (Annoura et al., 1996). A role for mGlu1 receptors in the antiproliferative effect of PHCCC was excluded by the inactivity of CPCCOEt and by the low levels of expression of $\mathrm{mGlu} 1$ receptors in the early stages of granule cell development (Copani et al., 1998). The action of PHCCC was attenuated by the group III mGlu receptor antagonists MSOP and MPPG, which also induced a slight increase in DNA synthesis when applied alone. Hence, PHCCC might inhibit GNP proliferation by amplifying the endogenous activation of mGlu4 receptors. $\mathrm{PH}-$ CCC inhibited $\left[{ }^{3} \mathrm{H}\right]$ thymidine incorporation to an unusually high extent (up to $80 \%$ in some experiments), and its efficacy varied in relation to the growing condi- 
Table 4. Inhibition of $\left[{ }^{3} \mathrm{H}\right]$ thymidine incorporation by PHCCC in cultured cerebellar granule cells treated with forskolin and with specific inhibitors of PI-3-K and MAPK

$\left[{ }^{3} \mathrm{H}\right]$ thymidine incorporation $(\mathrm{dpm} / \mathrm{dish}) \times 10^{-3}$

\section{Control}

$\operatorname{PHCCC}(30 \mu \mathrm{m})$

Forskolin $(10 \mu \mathrm{m})$

Forskolin plus $\mathrm{PHCCC}$

8Br-CAMP (1 mM)

8Br-cAMP plus PHCCC

LY294002 (10 $\mu \mathrm{m})$

LY294002 plus forskolin

LY294002 plus PHCCC

U0126 (10 $\mu \mathrm{m})$

U0126 plus forskolin

U0126 plus PHCCC

Cultures were exposed to drugs for $24 \mathrm{hr}$ V Values are means + SEM of nine determinations from three independent experiments. $p<0.05$ (1-way ANOVA plus Fisher's PLSD) versus control $\left({ }^{a}\right)$, PHCCC alone $\left({ }^{b}\right)$, or LY294002 or U0126 alone ( $)$.

tions. Reduction of $\left[{ }^{3} \mathrm{H}\right]$ thymidine incorporation was greater in the presence of $\mathrm{SHH}$ than in the presence of insulin. This is in line with the ability of PHCCC to reduce the expression of Gli-1 without inhibiting insulin signaling (see below). Insulin was still able to enhance GNP proliferation in PHCCC-treated cultures plated in BME alone, but not in those plated with serum or in CDM. This suggests that the interaction between mGlu4 receptors and insulin signaling is context dependent, although the interpretation of these results is biased by the presence of insulin in CDM and IGFs in serum, which might have desensitized insulin receptors during the initial drug-free period $(40 \mathrm{~min}$ ) after plating. PHCCC was not toxic to granule cells in culture, as assessed by $\mathrm{LDH}$ release or fluorescent chromatin staining. It was critical to determine whether PHCCC acted exclusively through the mGlu4 receptors or could have an antimitotic activity by itself. We addressed this issue by testing the drug in cells that did not express mGlu4 receptors. We found that PHCCC slightly reduced $\left[{ }^{3} \mathrm{H}\right]$ thymidine incorporation in $\mathrm{PC} 12$ cells incubated without serum and in mock HEK 293 cells. However, this reduction was smaller than that observed in cultured granule cells. Remarkably, reduction of $\left[{ }^{3} \mathrm{H}\right]$ thymidine incorporation by PHCCC was much greater in HEK 293 cells expressing mGlu4 receptors. A role for mGlu4 receptors was strengthened by the lack of activity of PHCCC in cultures from mGlu4 knock-out mice. It is reasonable to conclude that a small component of the antiproliferative activity of PHCCC is mediated by an intrinsic mechanism that is cell and context specific, whereas a large component is mediated by the activation of mGlu4 receptors. We attempted to explore the signaling pathway activated by PHCCC in cultured granule cells. Recombinantly expressed mGlu4 receptors are negatively coupled with adenylyl cyclase activity (for review, see De Blasi et al., 2001). In mature cultured granule cells, activation of mGlu4 receptors stimulates both the MAPK and the PI-3-K pathways and promotes cell survival through these mechanisms (D'Mello et al., 1993; Iacovelli et al., 2002). In our immature cultures, PHCCC inhibited forskolin-stimulated cAMP formation, and forskolin slightly attenuated the antiproliferative action of the drug. However, it is noteworthy that we could never detect an inhibition of basal cAMP formation by PHCCC and that a metabolically stable cAMP analog was inactive when combined with PHCCC. In addition, agents that stimulate cAMP formation are known to reduce GNP proliferation, and PACAP inhibits the mitogenic activity of SHH through the cAMP-protein kinase A pathway (Nicot et al., 2002). Thus, we conclude that enhancing mGlu4 receptor activation with PHCCC reduces the evoked adenylyl cyclase activity in cultured granule cells, but this effect has a small impact (if any) on GNP proliferation. Treatment with PHCCC did not reduce the strong stimulation of the MAPK and the PI-3-K pathways induced by insulin, and PHCCC still inhibited cell proliferation in the presence of the MAPK inhibitor UO126 and the PI-3-K inhibitor LY294002. We only found that PHCCC inhibited the small stimulation of the PI-3-K pathway induced by forskolin, but this effect cannot be related to the antiproliferative activity of PHCCC because forskolin alone did not enhance $\left[{ }^{3} \mathrm{H}\right]$ thymidine incorporation. Although these findings do not support a role for the MAPK and PI-3-K pathways in the action of PHCCC, we cannot exclude an involvement of these pathways because the effect of the two inhibitors on basal MAPK and PI-3-K activity could not be detected reliably because of the low sensitivity of the Western blot analysis of phosphorylated ERK1/2 and phosphorylated Akt. Thus, additional studies are needed to discover a role of the MAPK and the PI-3-K pathways in the action of PHCCC. An unexpected finding was that a

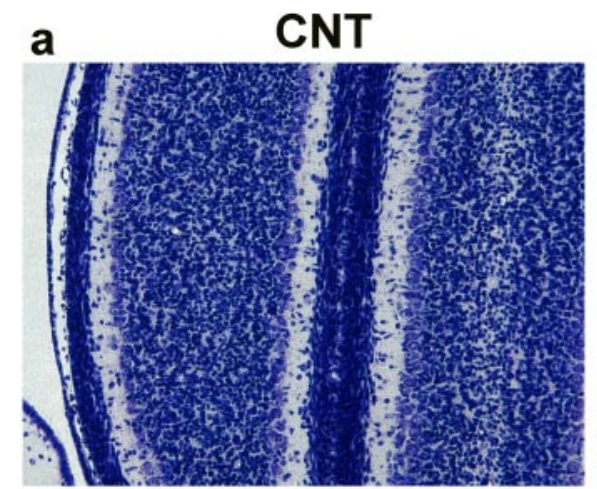

C

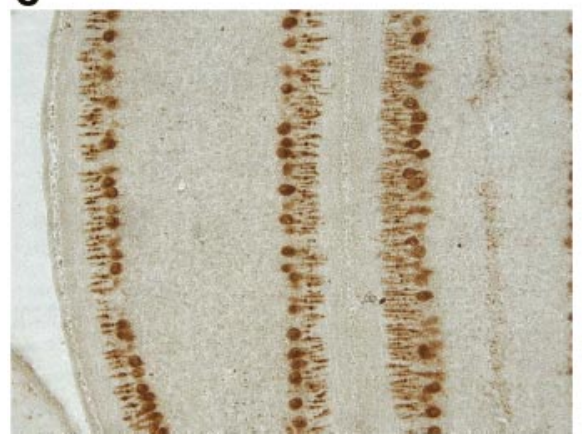

Figure 8. Nissl staining $(a, b)$ and calbindin immunostaining $(c, d)$ of comparable cerebellar sections from rats treated intracerebrally with vehicle or with $\mathrm{PHCCC}(5 \mathrm{nmol} / 2 \mu \mathrm{l} / 2$ min infused into the cerebellar region every other day from $\mathrm{P} 3$ to $\mathrm{P} 9)$. Animals were killed at $\mathrm{P} 10$. Note the cell reduction in the internal granular layer in the representative cerebellar section of a PHCCC-treated animal ( $b$ ). The same animal shows Purkinje cells with a dystrophic dendritic tree, as revealed by the calbindin immunostaining in d. These morphological abnormalities were observed in all PHCCC-treated animals.

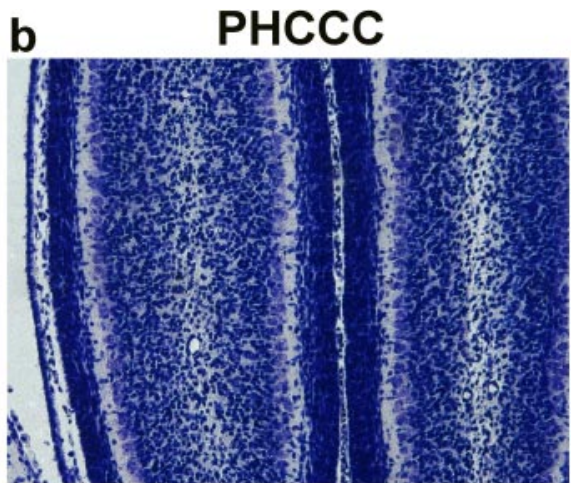

d

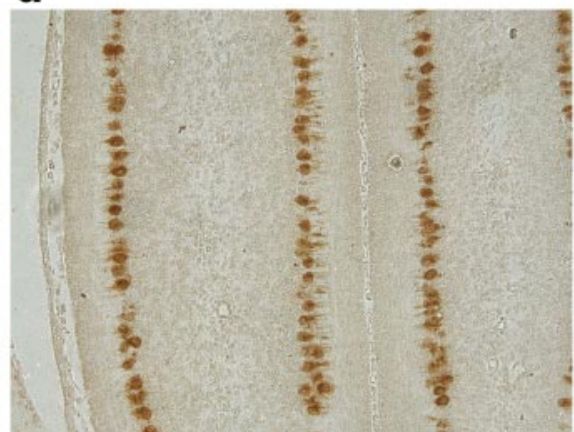


Table 5. Wet weight of the cerebellum in P21 rats treated with saline or PHCCC (5 $\mathrm{mg} / \mathrm{kg}$, i.p.) from P3 to P9

\begin{tabular}{ll}
\hline & Weight of cerebellum (percentage of body weight) \\
\hline Saline & $1.14 \pm 0.08$ \\
PHCCC & $0.83 \pm 0.09^{*}$ \\
\hline
\end{tabular}

Values are means \pm SEM of six determinations. ${ }^{*} p<0.05$ (Student's $t$ test).

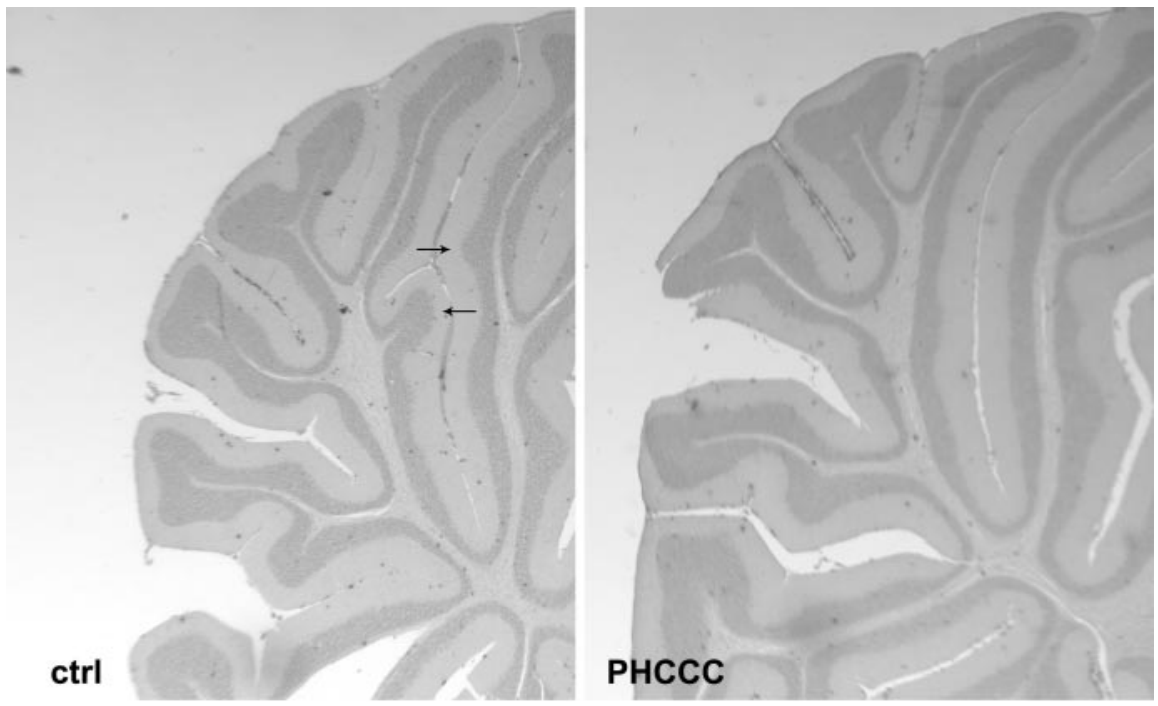

Figure 9. Repeated systemic injections of PHCCC ( $5 \mathrm{mg} / \mathrm{kg}$, i.p., once per day from P3 to P9) induced morphological abnormalities in lobule $V$ of the cerebellar cortex at P21. The arrows show the typical projections of the internal granular layer of lobule $V$ always present in rats treated with saline. These projections were absent in four of six rats treated with PHCCC.

short treatment with PHCCC reduced the levels of Gli-1, a transcription factor that lies downstream of the Patched-Smoothened receptor complex within the SHH pathway (Lee et al., 1994; Hynes et al., 1997; Ruiz-i-Altaba, 1998). This finding is highly relevant because expression of Gli-1 supports cell proliferation in many cell types. It will be interesting to explore whether mGlu4 receptors interact with the $\mathrm{SHH}$ pathway, which promotes GNP proliferation during cerebellar development (Dahmane and Ruiz-i-Altaba, 1999; Wallace 1999; Wechsler-Reya and Scott, 1999).

Based on these in vitro findings, we predicted that treatment with PHCCC could substantially affect cerebellar development in living animals. The most striking effect was seen in pups infused with PHCCC in the cerebellar region, which showed a substantial reduction in the size of the internal cerebellar granular layer and an impaired development of the dendritic tree of Purkinje cells, which may result from a deficient innervation by parallel fibers. Pups injected systemically with PHCCC (from P3 to P9) did not show apparent abnormalities in cerebellar development at the end of the treatment, perhaps because of a limited central bioavailability of the compound. However, $10 \mathrm{~d}$ later (i.e., at P21), rats treated with PHCCC showed a lower weight of the cerebellum and morphological abnormalities in lobule $\mathrm{V}$ of the central lobe, a region that develops at later times with respect to the anterior and posterior lobes. Interestingly, a similar lobuledependent effect was found by Katoh-Semba et al. (2002) after intracerebroventricular injection of anti-neurotrophin-3 antibodies, suggesting that central lobules are particularly sensitive to agents that affect cerebellar development. Taken together, these data are consistent with the hypothesis that activation of mGlu4 receptors negatively modulates GNP proliferation.
In conclusion, our data suggest that an amplified activity of mGlu4 receptors drives GNPs to exit the cell cycle and differentiate into mature granule cells. This has a high degree of specificity because drugs that selectively activate or inhibit other mGlu receptor subtypes did not affect GNP proliferation. The evidence that a $24 \mathrm{hr}$ exposure to PHCCC increased the number of neuriteexpressing cells suggests that activation of mGlu4 receptors promotes early events in neuritogenesis. However, the high receptor expression in differentiated cultured granule cells (D’Mello et al., 1993; Iacovelli et al., 2002) suggests that the mGlu4 receptor mediates processes that are important for the maintenance of a mature phenotype. Under physiological conditions, the control of GNP proliferation and differentiation mediated by mGlu4 receptors might be dispensable because mGlu4-/- mice develop normally and basal $\left[{ }^{3} \mathrm{H}\right]$ thymidine incorporation did not differ between cultured granule cells prepared from wildtype and mGlu4-/- mice (Table 3 ). It is the amplification of mGlu4 receptor activation or an overexpression of mGlu4 receptors (Fig. 6) that appears to promote GNP differentiation. An important implication of these findings is that pharmacological activation of mGlu4 receptors might control the excessive growth of pathological cells originating from GNPs, which give rise to medulloblastomas. Our evidence that the D-283 and D-341 medulloblastoma cell lines express mGlu4 receptors (our unpublished observations) suggests that this possibility is not remote and warrants investigation.

\section{References}

Altman J, Bayer S (1996) An overview of the postnatal development of the rat cerebellum. In: Development of the cerebellar system: in relation to its evolution, structure, and function, pp 324-333. Boca Raton, FL: CRC.

Annoura H, Fukunaga A, Uesugi M, Tatuoka T, Horikawa Y (1996) A novel class of antagonists for metabotropic glutamate receptors, 7-(hydroxyimino)cyclopropa[b]chromen-1a-carbozylates. Bioorg Med Chem Lett 5:223-228.

Cameron HA, McEwen BS, Gould E (1995) Regulation of adult neurogenesis by excitatory input and NMDA receptor activation in the dentate gyrus. J Neurosci 15:4687-4692.

Catania MV, Landwehrmeyer GB, Testa CM, Standaert DG, Penney Jr JB, Young AB (1994) Metabotropic glutamate receptors are differentially regulated during development. Neuroscience 61:481-495.

Catania MV, Bellomo M, Di Giorgi-Gerevini V, Seminara G, Giuffrida R, Romeo R, De Blasi A, Nicoletti F (2001) Endogenous activation of group-I metabotropic glutamate receptors is required for differentiation and survival of cerebellar Purkinje cells. J Neurosci 21:7664-7673.

Copani A, Casabona G, Bruno V, Caruso A, Condorelli DF, Messina A, Di Giorgi Gerevini V, Pin JP, Kuhn R, Knopfel T, Nicoletti F (1998) The metabotropic glutamate receptor mGlu5 controls the onset of developmental apoptosis in cultured cerebellar neurons. Eur J Neurosci 10:2173-2184.

Dahmane N, Ruiz-i-Altaba A (1999) Sonic hedgehog regulates the growth and patterning of the cerebellum. Development 126:3089-3100.

De Blasi A, Conn PJ, Pin J, Nicoletti F (2001) Molecular determinants of metabotropic glutamate receptor signaling. Trends Pharmacol Sci 22:114-120.

DiCicco-Bloom E, Black IB (1989) Depolarization and insulin-like growth factor-I (IGF-I) differentially regulate the mitotic cycle in cultured rat sympathetic neuroblasts. Brain Res 10:403-406. 
D'Mello SR, Galli C, Ciotti T, Calissano P (1993) Induction of apoptosis in cerebellar granule neurons by low potassium: inhibition of death by insulin-like growth factor I and cAMP. Proc Natl Acad Sci USA 90:10989-10993.

Dudek SM, Bear MF (1989) A biochemical correlate of the critical period for synaptic modification in the visual cortex. Science 246:673-675.

Flint AC, Dammerman RS, Kriegstein AR (1999) Endogenous activation of metabotropic glutamate receptors in neocortical development causes neuronal calcium oscillations. Proc Natl Acad Sci USA 12:12144-12149.

Follenzi A, Ailles LE, Bakovic S, Geuna M, Naldini L (2000) Gene transfer by lentiviralvectors is limited by nuclear translocation and rescued by HIV-1 pol sequences. Nat Genet 25:217-222.

Furuta A, Martin LJ (1999) Laminar segregation of the cortical plate during corticogenesis is accompanied by changes in glutamate receptor expression. J Neurobiol 39:67-80.

Gao WQ, Heintz N, Hatten ME (1991) Cerebellar granule cell neurogenesis is regulated by cell-cell interaction in vitro. Neuron 6:705-715.

Gould E, Cameron HA, McEwen BS (1994) Blockade of NMDA receptors increases cell death and birth in the developing rat dentate gyrus. J Comp Neurol 340:551-565.

Hahn H, Christiansen J, Wicking C, Zaphiropoulos PG, Chidambaram A, Gerrard B, Vorechovsky I, Bale AE, Toftgard R, Dean M, Wainwright B (1996) A mammalian patched homolog is expressed in target tissues of sonic hedgehog and maps to a region associated with developmental abnormalities. J Biol Chem 271:12125-12128.

Hannan AJ, Blakemore C, Katsnelson A, Vitalis T, Huber KM, Bear M, Roder J, Kim D, Shin HS, Kind PC (2001) PLC-beta1, activated via mGluRs, mediates activity-dependent differentiation in cerebral cortex. Nat Neurosci 4:282-288.

Heck S, Enz R, Richter-Landsberg C, Blohm DH (1997) Expression of eight metabotropic glutamate receptor subtypes during neuronal differentiation of P19 embryocarcinoma cells: a study by RT-PCR and in situ hybridization. Brain Res Dev Brain Res 18:85-91.

Huber KM, Sawtell NB, Bear MF (1998) Effects of the metabotropic glutamate receptor antagonist MCPG on phosphoinositide turnover and synaptic plasticity in visual cortex. J Neurosci 18:1-9.

Huber KM, Gallagher SM, Warren ST, Bear MF (2002) Altered synaptic plasticity in a mouse model of fragile X mental retardation. Proc Natl Acad Sci USA 99:7746-7750.

Hynes M, Stone DM, Dowd M, Pitts-Meek S, Goddard A, Gurney A, Rosenthal A (1997) Control of cell pattern in the neural tube by the zinc finger transcription factor and oncogene Gli-1. Neuron 19:15-26.

Iacovelli L, Bruno V, Salvatore L, Melchiorri D, Gradini R, Caricasole A, Barletta E, De Blasi A, Nicoletti F (2002) Native group-III metabotropic glutamate receptors are coupled to the mitogen-activated protein kinase/ phosphatidylinositol-3-kinase pathways. J Neurochem 82:216-223.

Iacovelli L, Capobianco L, Iula M, Di Giorgi Gerevini V, Picascia A, Blahos J, Melchiorri D, Nicoletti F, De Blasi A (2004) Regulation of mGlu4 metabotropic glutamate receptor signaling by type-2 G-protein coupled receptor kinase (GRK2). Mol Pharmacol 65:1103-1110.

Katoh-Semba R, Asano T, Ueda H, Morishita R, Takeuchi IK, Inaguma Y, Kato K (2002) Riluzole enhances expression of brain-derived neurotrophic factor with consequent proliferation of granule precursor cells in the rat hippocampus. FASEB J 16:1328-1330.

Kinzie JM, Saugstad JA, Westbrook GL, Segerson TP (1995) Distribution of metabotropic glutamate receptor 7 messenger RNA in the developing and adult rat brain. Neuroscience 69:167-176.

Lee JJ, Ekker SC, von Kessler DP, Porter JA, Sun BI, Beachy PA (1994) Autoproteolysis in hedgehog protein biogenesis. Science 266:1528-1537.

Lin X, Bulleit RF (1997) Insulin-like growth factor I (IGF-I) is a critical trophic factor for developing cerebellar granule cells. Brain Res Dev Brain Res 99:234-242.

Lo Turco JJ, Owens DF, Heath MJ, Davis MB, Kriegstein AR (1995) GABA and glutamate depolarize cortical progenitor cells and inhibit DNA synthesis. Neuron 15:1287-1298.

Maj M, Bruno V, Dragic Z, Yamamoto R, Battaglia G, Inderbitzin W, Stoehr N, Stein T, Gasparini F, Vranesic I, Kuhn R, Nicoletti F, Flor PJ (2003) (-)-PHCCC, a positive allosteric modulator of mGluR4: characterization, mechanism of action, and neuroprotection. Neuropharmacology 45:895-906.

Melchiorri D, Bruno V, Besong G, Ngomba RT, Cuomo L, De Blasi A, Copani A, Moschella C, Storto M, Nicoletti F, Lepperdinger G, Passarelli F (2001) The mammalian homologue of the novel peptide Bv8 is expressed in the central nervous system and supports neuronal survival by activating the MAP kinase/PI-3-kinase pathways. Eur J Neurosci 13:1694-1702.

Nicoletti F, Iadarola MJ, Wroblewski JT, Novelli A, Alho H, Guidotti A, Costa E (1986) The activation of inositol phospholipid hydrolysis as a signal transducing system for excitatory amino acids in primary cultures of cerebellar granule cells. J Neurosci 6:1905-1911.

Nicot A, Lelievre V, Tam J, Waschek JA, DiCicco-Bloom E (2002) Pituitary adenylate cyclase-activating polypeptide and sonic hedgehog interact to control cerebellar granule precursor cell proliferation. J Neurosci 22:9244-9254.

Nielsen HS, Hannibal J, Fahrenkrug J (1998) Expression of pituitary adenylate cyclase activating polypeptide (PACAP) in the postnatal and adult rat cerebellar cortex. NeuroReport 9:2639-2642.

Pekhletski R, Gerlai R, Overstreet LS, Huang XP, Agopyan N, Slater NT, Abramow-Newerly W, Roder JC, Hampson DR (1996) Impaired cerebellar synaptic plasticity and motor performance in mice lacking the mGluR4 subtype of metabotropic glutamate receptor. J Neurosci 16:6364-6373.

Pons S, Trejo JL, Martinez-Morales JR, Marti E (2001) Vitronectin regulates Sonic hedgehog activity during cerebellum development through CREB phosphorylation. Development 128:35-43.

Provias JP, Becker LE (1996) Cellular and molecular pathology of medulloblastoma. J Neuro-oncol 29:35-43.

Ruiz-i-Altaba A (1998) Combinatorial Gli gene function in floor plate and neuronal inductions by Sonic hedgehog. Development 125:2203-2212.

Schoepp DD, Jane DE, Monn JA (1999) Pharmacological agents acting at subtypes of metabotropic glutamate receptors. Neuropharmacology 38:1431-1476.

Schwartz HL, Ross ME, Oppenheimer JH (1997) Lack of effect of thyroid hormone on late fetal rat brain development. Endocrinology 138:3119-3124.

Skoglosa Y, Patrone C, Lindholm D (1999) Pituitary adenylate cyclase activating polypeptide is expressed by developing rat Purkinje cells and decreases the number of cerebellar gamma-amino butyric acid positive neurons in culture. Neurosci Lett 23:207-210.

Valerio A, Rizzonelli P, Paterlini M, Moretto G, Knopfel T, Kuhn R, Memo M, Spano P (1997) mGluR5 metabotropic glutamate receptor distribution in rat and human spinal cord: a developmental study. Neurosci Res 28:49-57.

Van den Pol AN, Kogelman L, Ghosh P, Liljelund P, Blackstone C (1994) Developmental regulation of the hypothalamic metabotropic glutamate receptor mGluR1. J Neurosci 14:3816-3834.

Wallace VA (1999) Purkinje-cell-derived Sonic hedgehog regulates granule neuron precursor cell proliferation in the developing mouse cerebellum. Curr Biol 22:445-448.

Wechsler-Reya RJ, Scott MP (1999) Control of neuronal precursor proliferation in the cerebellum by Sonic hedgehog. Neuron 22:103-114.

Ye P, Xing Y, Dai Z, D’Ercole AJ (1996) In vivo actions of insulin-like growth factor-I (IGF-I) on cerebellum development in transgenic mice: evidence that IGF-I increases proliferation of granule cell progenitors. Brain Res Dev Brain Res 20:44-54.

Zirpel L, Janowiak MA, Taylor DA, Parks TN (2000) Developmental changes in metabotropic glutamate receptor-mediated calcium homeostasis. J Comp Neurol 22:95-106. 